\title{
ON THE OCCURRENCE OF ICE DOMES AND PERMANENTLY SNOW-COVERED SUMMITS*
}

\author{
By Gordon Manley \\ (Bedford College, University of London)
}

\begin{abstract}
The occurrence of isolated ice- or snow-covered summits is reviewed. Their existence appears in the first place to be a function of their breadth in relation to the altitude of the firn line on adjacent glaciers; other factors remain to be discussed. Light may thus be thrown on questions of past glaciation of rounded summits in critical areas, and notably on the amount of precipitation then prevailing.
\end{abstract}

ZUSAMMENFassung. Es wird ein Überblick vom Vorkommen vereinzelter mit Eis oder Schnee bedeckten Gipfel gegeben. Ihre Existenz scheint in erster Linie eine Funktion ihrer Breite im Verhältnis zur Höhe der Firnlinie an angrenzende Gletscher zu sein; weitere Faktoren müssen noch besprochen werden. Fragen über die ehemalige Vergletscherung von abgerundeten Gipfeln in kritischen Zonen und besonders über die Menge des Niederschlags, die dann vorherrschte, mögen somit geklärt werden.

THE purpose of this note is to review the occurrence of permanent snow- and ice-accumulations on isolated summits of relatively small extent. The conditions under which more or less rounded summits become covered by accumulations of firn or ice are worthy of consideration in marginal areas, as they may throw light on the climatic conditions of the Ice Age. In Europe the most conspicuous example is of course Mont Blanc, but it is more rewarding to consider more marginal examples such as the Tête Blanche, Glittertind or Kebnekajse.

The lowest limit at which a permanently covered summit might exist is evidently but little above the firn line or climatic snow line, provided that its area is sufficiently extensive. Broadly speaking, the narrower the summit, the greater must be its height above the firn line in order to retain a snow cover. In addition to the area, the exact form of the summit no doubt plays some part, but once there is a permanent accumulation on the summit, the question of the roughness of the surface may be less important. Numerous problems of atmospheric and glacial physics, however, remain for elucidation; notably, how far the proportion of the snowfall which accumulates on the summit is affected by repeated freezing and thawing, or by changes in the character of the surface arising from the intermittent deposition of rime.

It is, however, evident that a typical Chamonix aiguille or, even more, the impressive peaks of Norwegian Antarctica can bear no snow at all. From any summit a proportion of the snow is removed by wind and what little may remain is often too thin to withstand radiation and other losses. The accumulation-ablation balance on an exposed summit differs from that on a glacier below, principally because the accumulation is greatly decreased owing to wind removal. On a rounded windswept summit such as Ben Nevis it may be very roughly estimated that the winter's accumulation is of the order of one-half that which would prevail in shelter below the summit. This estimate is derived from the measurements of snow accumulation made at the former Observatory ( $188_{4}-1903$ ).

When summits do carry a permanent snow cap, the amount of the cover appears to respond to the same factors governing the behaviour of the glaciers below. For example, the small cap on Kebnekajse is known to be diminishing in thickness. Likewise, in Iceland the small snow cap on Ok ( $1198 \mathrm{~m}$.) was described by T. Thoroddsen as a "firn-cupola" and is so contoured on the I/50,000 map (Uppdráttur Islands, I93I); but sketches by a party (Brathay Exploration Group) working on the summit in 1953 now show it as a snow-filled crater; in other words it has decreased in thickness, in association with the general retreat of glaciers.

Comparison of the character of snow summits can only be done very roughly, as the contouring on maps must perforce be approximate and changes may well have occurred since the

\footnotetext{
* Substance of a paper read at the tenth General Assembly of the I.U.G.G., Rome, 1954
} 
date of publication. This appears especially likely in the case of some of the minor snow summits on and around Jostedalsbreen. A rough but effective measure of area is, however, provided by measuring the breadth, more especially in the direction of the prevailing wind, of the ring or ellipse provided by the uppermost contours. Generally speaking these are at $30 \mathrm{~m}$. or $100 \mathrm{ft}$. intervals; and it is not difficult to estimate the breadth of the area lying within $30 \mathrm{~m}$. altitude of the actual summit. In what follows this will be referred to as the "breadth of the summit"; it forms a rough index of the "roundness."

A number of marginal examples may now be considered, chiefly in Norway: the first is that provided by Fanaråken $(2.068 \mathrm{~m}$.) of which the "breadth" is of the order of roo m. Around the summit observatory it is reported to be covered by snow on an average of about 300 days yearly. By extrapolation it can be estimated that this summit would need to be at least $2400 \mathrm{~m}$. high before it would bear a permanent cover. The firn line on the adjacent glaciers lies at about $1750 \mathrm{~m}$.

Nearby, the rounded top of Glittertind, breadth about $300 \mathrm{~m}$. at $244^{\circ} \mathrm{m}$., is completely covered ; the Galdhöpiggen (under $100 \mathrm{~m}$. broad, with summit $2468 \mathrm{~m}$.) is steeper, with a narrower summit and is not completely covered throughout the year. The firn line can be estimated to lie at about $1900-195^{\circ} \mathrm{m}$. on the glaciers around these summits. The mean temperature, JuneSeptember, at the summit level is about $-2^{\circ} \mathrm{C}$.; approximately the same figure holds for the snow-covered summit of Kebnekajse (2I $77 \mathrm{~m}$.).

Further east in Jotunheimen, Tjukningsubreen, north of L. Gjende, is shown on the maps to have a small snow summit at $2227 \mathrm{~m}$., $400-45^{\circ} \mathrm{m}$. broad. It is part of a glacier spreading over a remnant of the "2000 m." surface, which is, or was at the date of the maps (1935), upwards of $1.5 \mathrm{~km}$. broad above $2130 \mathrm{~m}$. But the adjacent summits at 2368 and $2305 \mathrm{~m}$., which are only about $150 \mathrm{~m}$. broad, do not carry a permanent snow cap.

Further north, however, the well-known Galdehöerne are rounded and very smooth summits, about $400 \mathrm{~m}$. "broad," with glaciers on both sides; yet even' at $225^{\circ} \mathrm{m}$. they are free from snow for a considerable period each summer. Likewise, the rounded Hestbrepiggene $(2157 \mathrm{~m}$.) and Loftet $(2170 \mathrm{~m}$.) are not covered. From O. H. Johnsson's map of precipitation in Norway (Geografiska Annaler, Årg. 19, I937, p. I12) it is evident that rather more snow falls on the mountains north of $\mathrm{L}$. Gjende than on the Galdehöerne, and this presumably explains why very similarly contoured summits just fail to be covered in the latter case. The respective adjacent firn lines are probably about 1800 and $2000 \mathrm{~m}$. From these comparisons it seems evident that a rounded summit $300 \mathrm{~m}$. "broad" will be likely to bear a snow cap it if rises $400 \mathrm{~m}$. above the locally prevailing firn line.

Inspection of the maps showing the numerous little snow domes around Jostedalsbreen suggests that the marginal instances are found at altitudes of $1600-165^{\circ} \mathrm{m}$. on the south side; some, indeed, may have disappeared since the surveys were made. Kvitekol $\left(163^{\circ} \mathrm{m}\right.$.) was upwards of I $\mathrm{km}$. in width; but not far away Asbjornnaase $(1630 \mathrm{~m}$.) was shown as a summit of similar breadth quite free from permanent snow. At a rather higher level Suphellenipa ( $1770 \mathrm{~m}$.), a rock summit about $150 \mathrm{~m}$. broad, was evidently not covered; but Grovebreen ( $1720 \mathrm{~m}$.) was a "snow dome" several kilometres wide.

On the Dovrefjell a narrower summit which just fails to be completely covered is that of Snöhetta $(2286 \mathrm{~m}$.); it rises 450 or even $500 \mathrm{~m}$. above the adjacent firn line, but is only about $100 \mathrm{~m}$. broad.

In Iceland, Snaefell ( $(1833 \mathrm{~m}$.) is a snow dome about $300-500 \mathrm{~m}$. broad (Jennings, J. N., fournal of Glaciology, Vol. 2, No. 12, 1952, p. 133), which appears to rise about $45^{\circ} \mathrm{m}$., perhaps more, above the average height of the adjacent firn line.

In southern Norway, Hardangerjökulen ( $1900 \mathrm{~m}$., ro km. wide) and Folgefonni ( $1674 \mathrm{~m}$, about $5 \mathrm{~km}$. wide) both rise well above the local firn line, and, as with Drangajökull ( $925 \mathrm{~m}$.) in Iceland, no very precise conclusions can be drawn as to the minimum breadth of summit which 
will allow a snow dome to develop in close proximity to the firn line. Marginal examples are also not easy to find in the Alps; for example, the Pigne d'Arolla and the Tête Blanche are of the order of roo m. wide but rise $800 \mathrm{~m}$. or more above the firn line. Some of the less steep summits of the Diablerets group (Wildhorn, Wildstrubel) are very nearly "snow domes" and stand 300$400 \mathrm{~m}$. above the local firn line as far as can be judged. I have not been able to find good examples in the Rockies.

It may thus be reasonable to say that in a disturbed temperate climate a summit $1000 \mathrm{~m}$. broad is likely to retain a snow cap and form a "dome," if it rises $200 \mathrm{~m}$. above the local firn line.
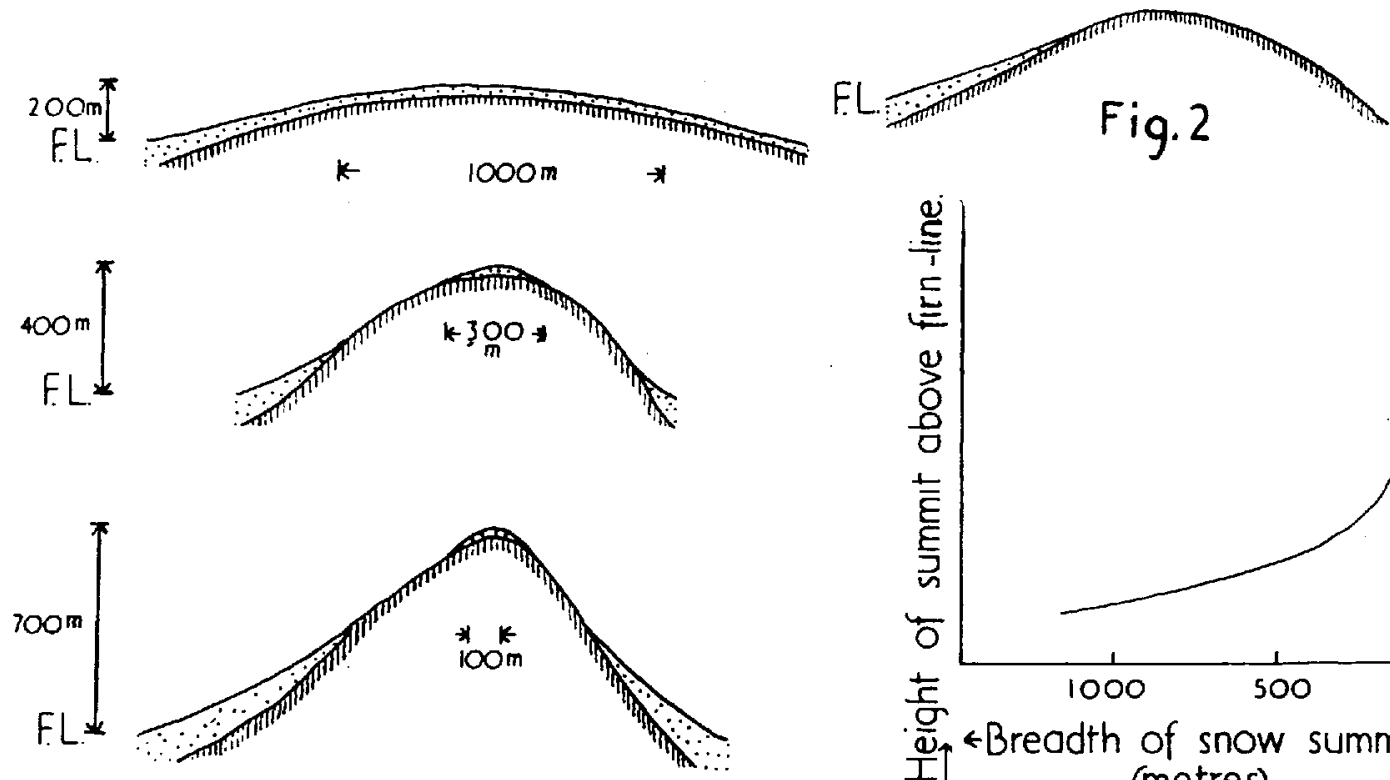

Fig. I

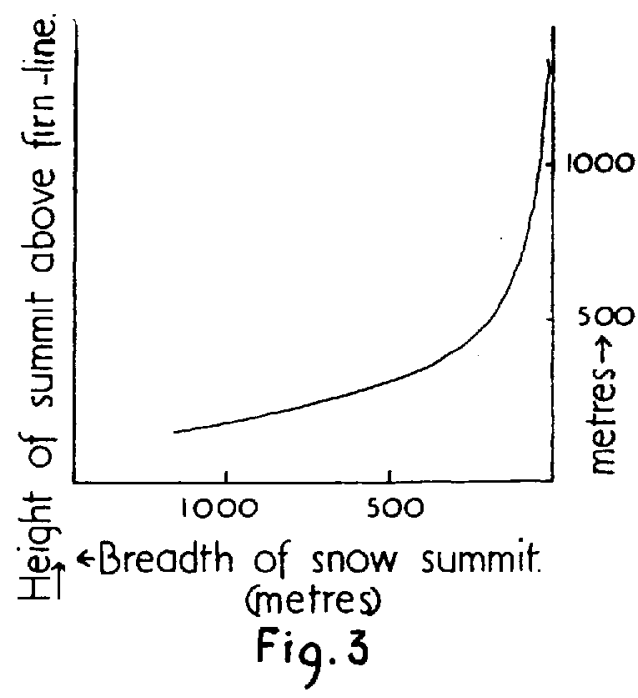

Fig. I. Probable contour of symmetrically disposed summits in relation to the firn line on adjacent glaciers

Fig. 2. Rounded summit not quite permanently covered by snow (Galdhö)

Fig. 3. Estimated form of the relationship between height and breadth of summits permanently covered by snow, and height of firn line on adjacent glaciers. The "breadth of a summit" is that between points $30 \mathrm{~m}$. below the highest point, estimated from the contours

A summit $300 \mathrm{~m}$. broad appears likely to retain a snow cap $400 \mathrm{~m}$. above the firn line; and perhaps one might estimate that a summit only $100 \mathrm{~m}$. broad would be unlikely to retain a permanent cap unless it attained a height of the order of $600-700 \mathrm{~m}$. above the firn line shown on its flanking glaciers. These figures provide the basis of the curve above.

The application of this discussion to problems of past glaciation will now emerge. In England the evidence favours the view that, whereas the Eden valley was filled with ice to a depth reaching $700 \mathrm{~m}$. on the flanking mountains, the summit of Crossfell $\left(893 \mathrm{~m}\right.$., and $35^{\circ}-5^{\circ 0} \mathrm{~m}$. broad) was never covered by moving ice. This would appear to require a firn line in that neighbourhood of $550 \mathrm{~m}$. at least, perhaps even $600 \mathrm{~m}$., compared with only $300 \mathrm{~m}$. in the Lake District mountains $30-40 \mathrm{~km}$. further west (Manley, G., Geographical fournal,. Vol. Ir7, No. I, 195 I, p. 43). Such a rise would testify to a rapid eastward decrease of precipitation.

D. L. Linton (fournal of Glaciology, Vol. 1, No. 8, 195\%, p. 45r ; Irish Geography, Vol. 2, No. I, 1949, p. 25) has posed a much more difficult problem in the Cairngorms; he considers 
that the evidence (upstanding granitic “tors") demands unglaciated, yet smooth and rounded summits up to altitudes of the order of $\mathrm{I} 100 \mathrm{~m}$., in spite of the very abundant glaciation below. Moreover, the slopes are such that one cannot imagine the ice standing still. In the previouslycited paper (195I) I have brought forward the evidence for a firn line at only about $130 \mathrm{~m}$. in north-western Scotland; whereas Linton's evidence would appear to demand a firn line not lower than $500 \mathrm{~m}$. on the eastern Cairngorms when glaciation was at its maximum. This may again throw light on the question of the amount of precipitation, and its eastward decrease; it lends support to the remarkably rapid eastward diminution proposed by A. Klein (Petermanns Geographische Mitteilungen, Quartalsheft 2, 1953, p. 98-104.)

It is just possible that a close investigation of the breadth of summits on which snow can accumulate, in relation to the firn line, might reconcile Linton's evidence for unglaciated summits with events at lower levels. Similar studies might be found to have an application in eastern North America. In any event the physics of accumulation on such summits deserves further study.

It is observed that in this note the term "firn line" refers to that prevailing on the glaciers surrounding the summits under discussion; and that each isolated snow summit may therefore possess a distinct "equilibrium-line" of its own.

Field investigations in Norway have been carried out with the aid of a grant from the Central Research Fund of the University of London, whose assistance is gratefully acknowledged.

$M S$. received I 6 November I954

\title{
THE BALANCE OF THE GRENLAND ICE SHEET
}

\author{
By Albert Bauer \\ (École Nationale d'Ingénieurs de Strasbourg)
}

\begin{abstract}
Planimetry of the is maps of scale i : I,000,000 of the World Aeronautical Chart, U.S.A.F., gives $1.726 \times 10^{6} \mathrm{~km} .2$ for the surface area of the Greenland Ice Sheet. The hypsometric curve obtained by measuring the area between contours at $1000-\mathrm{ft}$. (305 m.) intervals with a planimeter gives $2135 \mathrm{~m}$. for the mean height of the ice sheet. The normal area distribution curve of the ice sheet shows that is certainly in the "Inland Ice" type in Ahlmann's classification. The mean firn line of the ice sheet is at a height of $1390 \mathrm{~m}$. The discharge from the glaciers in the form of icebergs is estimated to be $215 \mathrm{~km} .{ }^{3}$ of water per year, and the nett balance of the ice cap is negative and about roo $\mathrm{km}^{3}$ of water per year.
\end{abstract}

RÉSumÉ. La planimétrie des ${ }_{5}$ feuilles au I : I.000.000 ème de la "World Áeronautical Chart, U.S.A.F.," donne $1,726 \times 1^{6} \mathrm{~km}^{2}$ pour la surface de l'Inlandsis du Groenland. La courbe hypsométrique déduite de la planimétrie des surfaces entre les isohypses d'intervalle 1000 pieds $(305 \mathrm{~m})$ donne $2135 \mathrm{~m}$ pour l'altitude moyenne de l'Inlandsis. La courbe normale de distribution des surfaces de l'Inlandsis montre que celui-ci entre bien dans la type "Inland Ice" de la classification d'Ahlmann. La ligne de névé moyenne de l'Inlandsis est à l'altitude I $390 \mathrm{~m}$. La décharge des glaciers sous forme d'icebergs est estimée à $215 \mathrm{~km}^{3}$ par an et le bilan de l'Inlandsis est négatif d'environ $100 \mathrm{~km}^{3}$ d'eau par an.

\section{INTRODUCTION}

Numerous studies old and new have been devoted to the Greenland Ice Sheet. Of all these that of Loewe is the most remarkable. ${ }^{1}$ It was based on a collection of all the data available in $193^{6}$ on the accumulation and ablation of the different zones of the ice sheet. The surface data were taken from the Danish map of Greenland at I : 5,000,000 on which he had traced the edge of the ice sheet.

Loewe's work now needs to be repeated using new data. We possess to-day in the I 5 sheets of the American World Aeronautical Chart ${ }^{2}$ a source of geographic information of the first order that supersedes the Danish map of Greenland. ${ }^{3}$ The American maps have the advantage that they give details of the contact between the ice sheet and the ice-free land; and they have contours at every $1000 \mathrm{ft}$. $(305 \mathrm{~m}$.). Fürther, even if Expéditions Polaires Françaises had not 